Dr. J. B. Ambrosetti as president; VI. Physics and chemistry, under the presidency of Dr. E. H. Ducloux, who discussed the chemistry of chlorophyll; VII. Applied science, presided over by Dr. T. Amadeo, who urged the importance of a well-organised national institute for agricultural research; and VIII. Teaching and history of natural science, presided over by Prof. V. Mercanti, who discussed the teaching in the national colleges and normal schools. Papers were numerous, especially in reference to Tucuman, and among the evening lectures was a valuable discourse by Dr. Hermitte on the petroleum worked at Comodoro Rivadavia.

The next congress is to be held at Mendoza, and it is hoped meanwhile to establish in all the provincial capitals institutes or societies to work in association with the Argentine society.

\section{EDUCATIONAL RECONSTRUCTION.}

\section{T}

$\mathrm{HE}$ appreciation of the urgent need for an immediate improvement and extension of the supply of educational facilities for all sections of the population is common alike to administrators of education and to teachers of all grades. During recent months special meetings of associations of educational workers of many types have been held, at which reports and resolutions have been adopted, which summarise the experience gained in various localities and in all kinds of educational institutions.

One of the latest competent authorities to issue a report on educational reform is the Association of Education Committees. Since June of last year the executive committee of this association has been considering important educational questions, with the object of contributing help to our administrators in the task of educational reconstruction to which they are committed. It is impossible here to enumerate all the recommendations included in the comprehensive report recently issued by the association, but attention is directed to the importance attached in the report to the necessity for an adequate provision of instruction in science. The general tenor of the replies to a question on the subject from education committees throughout the country is that in the elementary schools the rudiments only of science can with advantage be taught, between the ages of twelve and fourteen, and that it is not desirable to extend the range of the science teaching given in these schools much, if any, further than at present. In secondary schools, however, there is a large majority in favour of an increase of science teaching. With this view the executive committee concurs, but thinks that the science teaching to be given in elementary schools should be made general, and should proceed upon much more definite and systematic lines than it does now. In many schools science is the last subject considered in framing the time-table, and any kind of equipment, or none at all, is often crinsidered adequate, while the training of teachers, other than specialists, for giving good lessons in science is often very defective. The committee desires to record its emphatic opinion that it is essential in the best interests of the nation that much more attention should be given to the teaching of physical science in every type of school. It should be made impossible for any child to leave school without having had a full opportunity of learning at least the basic principles of science. In elementary schools the teaching can only be elementary, but, even so, it must be adequate. In secondary schools science should be the basis of the teaching on the "modern side," and that side should be of equal standing with any other. The mistaken view which puts science in antagonism to the older NO. 2487 , VOL. 997 features of a liberal education should be vigorously combated.

So far as continuation classes are concerned, the report reveals some diversity of opinion. Of the one hundred and two education committees which replied to the question on the desirability of compelling children who have left school to attend classes for further education, only twelve were opposed to the introduction of compulsion. Of the remainder, a few would carry on the further education only to the age of sixteen or seventeen, while sixty-five were in favour of compulsion up to eighteen. On the important point whether such education should be given in the daytime, or in the evening as now, only eight committees out of one hundred and six were in favour of a continuance of entire evening teaching, though some others thought that a part of it might be given in the evening.

The Association of Directors and Secretaries for Education, which includes the chief administrative officers for counties and county boroughs throughout England and Wales, has issued a series of resolutions dealing with important educational questions requiring legislative or administrative action. Among the resolutions of particular interest are the following :In the interests of the State no child or young person should be debarred by lack of means from the highest education of which it is capable. The upper limit of compulsory full-time attendance at the elementary school should be raised universally to fourteen years. The power of local education authorities to supply or aid the supply of education other than elementary, as provided by the Education Act, I902, should remain unimpaired. It should be the duty of local education authorities to make adequate provision of such forms of higher education as are needed for their areas. The limitation of the amount which may be raised by rate under the Education Act, 1902, section 2 (I), should be removed. It is desirable in the interests of educational efficiency as well as of economy that the Board of Education should resume its statutory powers with regard to agricultural education and should provide itself with the necessary expert staff. A system of compulsory day continuation schools should be established, with a minimum of eight hours' instruction per week, or at least 320 hours per year, between the ages of fourteen and eighteen years, the instruction to be given between the hours of 8 a.m. and 6 p.m. An obligation should be laid (r) on all employers to allow full time for instruction, including time for travelling, without deduction of wages; (2) on parents and pupils as to attendance; and (3) on local education authorities to make the necessary provision. The total hours of labour and of school attendance during the continuation-school period should not exceed forty-eight per week. The possession of an approved certificate testifying to the completion of a satisfactory course in a secondary school ending not earlier than sixteen years of age should entitle the holder to exemption from compulsory continuation-school attendance between sixteen and eighteen vears of age Adequate provision of scholarships from elementary schools to secondary and technical schools, and from secondary schools to places of higher education of university rank, should be an integral part of each authority's scheme.

The Association of Technical Institutions also has drawn up a programme of educational reform, with special reference to technical instruction, which should assist the Board of Education in its important task of extending and completing our system of national education.

A special committee was appointed by the association consisting of the council and six representatives 
of institutions outside the council. This committee has formulated a series of resolutions, which are now issued with the general approval of the members of the association, and among them the following may be noted :-

That the Government be asked to prevent any child leaving schoo! before the end of the term in which the child attains its fourteenth birthday; that the State should make adequate grants for the maintenance of free scholars proceeding from primary schools to secondary and junior technical schools; that there shall be instituted compulsory attendance at continuation classes up to the age of eighteen years, such attendance to be made in the daytime, and the period of instruction to be not less than eight hours per week, such hours to be within the normal hours of employment; that the conditions for admission to universities should be reconsidered and rendered more uniform as between different universities, and less uniform as between different faculties and different honours schools in the same university, and that in the interest of candidates of mature age and of other candidates approaching the university otherwise than through the normal avenue of the secondary school, university entrance tests should be distinguished from secondary-school examinations; that it is desirable that there should be a large increase in the number of scholarships with adequate maintenance grants to enable candidates to proceed to day technical colleges; that teachers in technical departments of universities and technical colleges be encouraged to undertake research on behalf of, and in co-operation with, manufacturing firms: that in view of the national import. ance of technical education the State should bear a much larger proportion of its cost than is now the case; that Government grants in aid of technical research should be largely increased; that it is essential that the chief officials of the Technological Branch of the Board of Education should have had a scientific training; and that the examinations of the Civil Service and for other Government appointments, when not directly on the subjects of the service, should include such science subjects and syllabuses, and should be so marked as will give the student with a scientific training an equal chance with a student who has had a literary training.

\section{UNIVERSITY AND EDUCATIONAL INTELLIGENCE.}

London.-The Senate has elected Sir Cooper Perry, physician at, and superintendent of, Guy's Hospital, to the office of Vice-Chancellor for the year $x 917-18$, in succession to Sir Alfred Pearce Gould.

The thanks of the Senate have been accorded to the Right Hon. Lord Reay, K.T., for the gift of a portion of his library to the University for the University College libraries, and to $\mathrm{Mr}$. George Hare for the gift of 50 . to found a zoology prize at King's College, in memory of his son, a medical student, who was killed at the battle of Gaza.

The following doctorates have been conferred:D.Sc. in Physiology, Mr. S. W. Patterson, an internal student, of University College, for a thesis entitled "The Action of Carbon Dioxide and Adrenalin on the Heart"; D.Sc. (Economics), Mr. J. E. Holloway, an internal student, of the London School of Economics, for a thesis entitled "The Prelude to the Great Trek"; D.Sc. in Zoology, Mr. Cyril Crossland, an external student, for a thesis entitled "Desert and Water Gardens of the Red Sea," and other papers.

OxForD.-Sir Napier Shaw, Director of the Meteorological Office, has been appointed Halley lecturer for I9I8.

NO. $248 \hat{7}$, VOL. 99]
The School of Geography has published its arrangements for the ensuing Michaelmas term. These include lectures, tutorial instruction, and field work. Among the subjects announced are:-"Maps: their Construction and Interpretation"; "The Alps and Northern Italy," Mr. Beckit; "The British Isles," Miss MacMunn; "Eastern Australia and New Zealand," Mr. Spicer; "Geology," Prof. Sollas; and "Historical Greography of Great Britain," Mr. Grant Robertson.

A list of lectures and other courses of instruction for the forthcoming term has also been issued by the Department of Anthropology. In physical anthropology lectures will be given by Prof. Thomson and by Miss Czaplicka, the latter on ethnology. The geographical distribution of man will be dealt with by Mr. Beckit. Mr. H. Balfour, Prof. Sollas, and Mr. Griffith will lecture respectively on prehistoric archæology, on stages of human culture, and on ancient Egypt. Various topics of social anthropology will be taken in hand by Dr. Marett, Sir P. Vinogradoff, Prof. Macdonell, Mr. V. A. Smith, and Mr. Blunt. Prof. Wright will lecture on philology, and Prof. J. A. Smith on primitive language in its relation to thought.

Mr. T. H. Bickerton has been appointed lecturer on ophthalmology in the University of Liverpool in succession to Mr. E. A. Browne, who has resigned the position.

ThE title of Emeritus professor has been conferred upon Col. de Burgh Birch, until lately professor of physiology and histology, and dean of the faculty of medicine, in the University of Leeds.

THE proceedings at the annual general meeting (March 29) of the Council of Education, Witwatersrand, published in a report just received from Johannesburg, show that we were right in our article of August ro last year when we said that apparent grievances and jealousies would end in a unanimous effort to establish a real university for Witwatersrand. We wish we could hope that the present entrance examination for the diploma of the School of Mines might be regarded as sufficient for matriculation in the new university, at all events for under. graduates proceeding to science degrees.

AMONG the many problems connected with engineering upon which experience gained during the war has shed fresh light is that of the workshop training of apprentices. An article which appears in Engineering for June 22, by $\mathrm{Mr}$. Neil J. Maclean, gives an interesting account of the system which has been in operation for twelve years at the works of Messrs. Barr and Stroud, Ltd., Glasgow. The author lays down six axioms which should be borne in mind in instituting any apprenticeship system. (I) The apprentice must be always busy, thus necessitating the time and attention of a skilled man. (2) The apprentice must be always learning; he must be taught to do a certain thing properly, and must then be moved on to a different kind of work. (3) Engineering is an exact science, and the apprentice must develop the scientific mind; to obtain the desired result, the training must involve an intimate mingling of practical and theoretical work, of shop experience and study, of things seen and done, things noted and written down. (4) The apprentice's course of training must not be determined by the shop foreman or manager responsible for output; in our opinion, the author touches a fruitful source of grievance here. A lad does well at a certain job, and the foreman keeps him at it in order to maintain output, regardless of the loss of experience to the apprentice and the ultimate loss to the firm. 